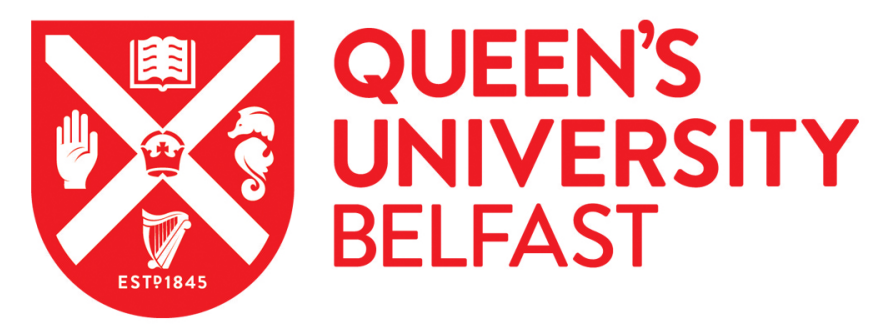

\title{
Control Patterns in Contracting-Out Relationships: It Matters What You Do, Not Who You Are
}

Ditillo, A., Liguori, M., Sicilia, M., \& Steccolini, I. (2015). Control Patterns in Contracting-Out Relationships: It Matters What You Do, Not Who You Are. Public Administration, 93(1), 212-229.

https://doi.org/10.1111/padm.12126

Published in:

Public Administration

Document Version:

Peer reviewed version

Queen's University Belfast - Research Portal:

Link to publication record in Queen's University Belfast Research Portal

Publisher rights

(c) 2014 John Wiley \& Sons Ltd.

This is the peer reviewed version of the following article: DITILLO, A., LIGUORI, M., SICILIA, M. and STECCOLINI, I. (2015), CONTROL PATTERNS IN CONTRACTING-OUT RELATIONSHIPS: IT MATTERS WHAT YOU DO, NOT WHO YOU ARE. Public Administration, 93: 212-229., which has been published in final form at doi: 10.1111/padm.12126. This article may be used for non-commercial purposes in accordance with Wiley Terms and Conditions for Self-Archiving.

\section{General rights}

Copyright for the publications made accessible via the Queen's University Belfast Research Portal is retained by the author(s) and / or other copyright owners and it is a condition of accessing these publications that users recognise and abide by the legal requirements associated with these rights.

Take down policy

The Research Portal is Queen's institutional repository that provides access to Queen's research output. Every effort has been made to ensure that content in the Research Portal does not infringe any person's rights, or applicable UK laws. If you discover content in the Research Portal that you believe breaches copyright or violates any law, please contact openaccess@qub.ac.uk. 


\title{
Control patterns in contracting-out relationships: it matters what you do, not who you are
}

Manuscript for Public Administration, 93, 1, 2015

\author{
Angelo Ditillo \\ Associate professor, Bocconi University, Milan \\ angelo.ditillo@unibocconi.it \\ Mariannunziata Liguori (corresponding author) \\ Lecturer, Queen's University, Belfast \\ m.liguori@qub.ac.uk. \\ Mariafrancesca Sicilia \\ Assistant Professor, Bergamo University, Bergamo \\ mariafrancesca.sicilia@unibg.it \\ Ileana Steccolini \\ Associate professor, Bocconi University, Milan \\ ileana.steccolini@sdabocconi.it
}




\title{
Control patterns in contracting-out relationships: it matters what you do, not who you are ${ }^{1}$
}

\begin{abstract}
The contracting-out of public services has often been accompanied by a strong academic focus on the emergence of new governance forms, and a general neglect of the processes and practices through which contracted-out services are controlled and monitored. To fill this gap, we draw on contracting-out and inter-organizational control literatures to explore the adoption of control mechanisms for public service provision at the municipal level and the variables that can explain their choice. Our results, based on a survey of Italian municipalities, show that in the presence of contracting-out, market-, hierarchy- and trustbased controls display different intensities, can co-exist and are explained by different variables. Service characteristics are more effective in explaining market- and hierarchybased controls than relationship characteristics. Trust-based controls are the most widespread, but cannot be explained by the variables traditionally identified in contractingout and inter-organizational control studies.
\end{abstract}

Keywords: contracting-out, municipalities, control, public services.

\footnotetext{
${ }^{1}$ The authors are listed in alphabetical order. They wish to thank Noel Hyndman and the anonymous reviewers for their insightful suggestions on former drafts of the paper and the editor for his support. The paper is the result of a research project funded by the 'Demattè' Research Division of SDA Bocconi School of Management. The research assistance of Andrea Orlandi and Silvia Rota are gratefully acknowledged.
} 


\section{Introduction}

Over the last decades, governments have increasingly moved from the direct provision of services to contracting them out (Brown and Potoski 2003; Van Slyke 2003; Bovaird 2006; Brown et al. 2006), giving rise to the emergence of new governance forms where public and private actors and interests interact (Miller et al. 2008; Beriv and Rhodes 2003). This requires the development of new systems to manage the contracting process, from the assessment of its feasibility, to its implementation, to its monitoring and evaluation (Johnston and Romzek 1999; Romzek and Johnston 2002; Brown and Potoski 2003; Van Slyke 2007).

Much literature has focused on the identification of the most efficient governance forms to provide the service (the first stage of the contracting process) (Johnston and Romzek 1999; Brown and Potoski 2003; Bel and Warner 2008; Hefetz and Warner 2012). In the light of the interest in contracting-out issues shown by many scholars, it is perhaps surprising that the phases of monitoring and evaluation of contracted-out public services have rarely been investigated (Miller et al. 2008). This neglect often reflects the limited attention towards the phase of contract evaluation (Kettl 1993; Brown and Brudney 1998; Sclar 2000), which sometimes translates into a deficit of monitoring and, in general, contract management capacity (Brown and Potoski 2003; Van Slyke 2007). Consequently, calls have been made to better understand such monitoring practices in view of their importance in ensuring the effectiveness of contracting-out (Johnston and Romzek 1999; Romzek and Johnston 2002; Cristofoli et al. 2010).

This paper combines contracting-out (Donahue 1989; Hefetz and Warner 2012; Marvel and Marvel 2007; Van Slyke 2007) and the inter-organizational control (Van der Meer-Kooistra 
and Vosselman 2000; Langfield-Smith and Smith 2003; Caglio and Ditillo 2008a, 2008b) literatures to explore variables relating to the adoption of control mechanisms for public service provision at the municipal level. The contribution is twofold. First, by combining the traditional contracting-out and the inter-organizational control literatures, we explore whether the variables traditionally used to explain contracting-out choices have explanatory potential. Second, differently from previous studies, we consider both the intensity and the types of control (i.e. hierarchical, market-based and trust-based). The analysis is based on a survey of Italian municipalities, where public services have been increasingly contracted out, requiring the deployment of a combination of controls over the public-service providers. The paper is structured as follows: the next section reviews the relevant literature on monitoring and control systems in public service provision; this is followed by a discussion of types of control and possible explanatory variables regarding choice of control method (as a basis for developing two propositions); subsequent sections outline the research methods, the results and a discussion of the results; and the final section draws conclusions and suggests further research avenues.

\section{Monitoring and control systems in public-service provision}

The contracting-out literature has mainly focused on outsourcing forms and their determinants (Brown and Potoski 2003; Van Slyke 2003; Bel and Warner 2008; Hefetz and Warner 2012; Albalate et al., 2013). Contracting-out behaviors have been studied looking at service-delivery choices and consequences, often adopting a transaction-cost approach and proposing explanatory variables, such as asset specificity, output measurability, task uncertainty and task interdependence (Ferris and Graddy 1991; Milward and Provan 2000; 
Brown and Potoski 2003; Malatesta and Smith, 2014). In a comprehensive analysis of contracting-out, Hefetz and Warner (2012) find that the most important factors explaining delivery mode choices (in-house, delivery by government, by for-profit or non-profit entities) are the extent of market competition, citizen involvement and the place characteristics.

Only a few studies, drawing mainly on economic theories, such as transaction-cost economics (Williamson 1981) and agency theory (Jensen and Meckling 1996), have focused on the monitoring of public services in contracting-out contexts. According to these, monitoring systems are put in place in order to minimize transaction costs and goal misalignment between principal and agent. However, Van Slyke (2007) finds that the degree of variance in the level of monitoring is much lower than expected, and he suggests that both agency theory and rational management theory (related to goal congruence issues) have strong explanatory limitations. He also argues that the explanation of different monitoring devices in different public services may necessitate the adoption of alternative theoretical perspectives. Contrary findings are presented by Marvel and Marvel (2007), who investigate the intensity of monitoring mechanisms contrasting transaction-cost and performance-measurement literatures. They find that, consistently with literature expectations, the delivery mode (in-house, delivery by government, by for-profit or nonprofit entities) can actually affect the intensity of the controls put in place as a consequence of the divergence in the provider's goals. Their study shows that the intensity of ex-ante process and ex-post monitoring does not differ between in-house and for-profit provision. Furthermore, Marvel and Marvel (2008) also suggest that intrinsic service characteristics, such as asset specificity and ease of measurement, may also contribute in determining the intensity of controls. Services which generate more monitoring, indeed, do so 
independently of the type of delivery mode. Finally, Brown and Potoski (2003) point out that governments that contract out tend to calibrate their monitoring on the basis of the transaction-cost risks attributable to a certain service and to the contracting environment.

The above contributions only consider the intensity of controls in contracted-out public services. More recently, Cristofoli et al. (2011) have gone further, looking at the types of controls (i.e. market-, hierarchy and trust-based) put in place and widening the range of variables and characteristics that can explain them. Control patterns tend to combine and, while environmental (uncertainty and asset specificity) and task ( output measurability and task programmability) characteristics only partially explain the adoption of certain control configurations, control mechanisms seem to be influenced by party characteristics (partner knowledge, ownership configuration and political visibility). However, their limited study (of nine cases) did not consider variables such as delivery mode, political orientation, and financial performance.

Bringing together the inter-organizational control and the contracting-out literatures (so far used separately), this paper aims at providing a more comprehensive view of the monitoring and control mechanisms of contracted-out public services. In particular, we contribute to this (very limited) literature by: exploring, through a survey, whether the variables used to explain contracting-out choices have explanatory potential (particularly with reference to the subsequent control mechanisms established); and considering the impact of different types of controls (i.e. hierarchical, market-based or trust-based).

\section{Types of control and explanatory variables}


The literature on control mechanisms has traditionally identified three ideal-types: market-, hierarchy- and trust-based controls (Van der Meer-Kooistra and Vosselman 2000; Langfield-Smith and Smith 2003; Håkansson and Lind 2004). This literature defines market-based patterns of control as those where the information necessary to regulate transactions is included in the price, linked to standardized activities and outputs (Caglio and Ditillo 2008a), competitive bidding takes place at periodic intervals and contracts are characterized by a low level of detail (Langfield-Smith and Smith 2003). Hierarchy-based patterns of control are those based on behavioural controls, where detailed contracts should be used to monitor the performance, and control mechanisms include specified norms, standards, detailed rules and rigid performance targets. The aim of these controls is to guarantee continuous supervision, performance measurement and evaluation (van der Meer-Kooistra and Vosselman 2000; Langfield-Smith and Smith 2003). Finally, trustbased patterns are generally described as substitutes or complements for formal control mechanisms (Dekker 2004; Das and Teng 1998), based on social controls, broad nonspecific contracts and emergent performance assessment standards, personal consultation and intensive communication to generate confidence that the other parties will not behave opportunistically (Langfield-Smith and Smith 2003).

It has to be noted that these three control types represent extremes on a spectrum, and we might expect that, in reality, different combinations of these forms exist (Caglio and Ditillo 2008a; Spekle 2001). Moreover, as suggested by previous literature (Spekle 2001; Caglio and Ditillo 2008a; Miller et al. 2008), it is worth remembering that the concept of governance form or structure is different from the concept of control. Indeed, within the same mode of governance a variety of different control models is possible (Spekle 2001). 
Both the inter-organizational control and contracting-out literatures have traditionally relied on transaction-cost economics, identifying variables such as output measurability, task uncertainty and asset specificity as explanatory factors for control choices and contractingout decisions (Brown and Potoski 2003; Van Slyke 2003; Romzek and Johnston 2002; Bel and Warner 2008). However, other variables might aid explanation, as Hefetz and Warner (2012) show for contracting-out, and Cristofoli et al. (2011) suggest for control decisions. Drawing on previous studies, two main sets of variables can be identified: service and relationship characteristics. Their features and expected effects are discussed in the next sub-sections.

\section{Explanatory variables: Service characteristics}

Existing inter-organizational control literature mainly refers to service characteristics in terms of asset specificity, task uncertainty, task interdependence and output measurability (Ferris and Graddy 1991; Milward and Provan 2000; Brown and Potoski 2003; Marvel and Marvel 2008; Van der Meer-Kooistra and Vosselman 2000; Langfield-Smith and Smith 2003). Services characterized by low asset specificity and task interdependence, and high output measurability, are expected to be associated with market-based types of controls. When the final service output is less predictable and less commodified (the level of task uncertainty ranges from medium to high), and services are characterized by moderate asset specificity, task interdependence and output measurability, hierarchy-based patterns seem to be more suitable (van der Meer-Kooistra and Vosselman 2000; Langfield-Smith and Smith 2003; Caglio and Ditillo 2008a, 2008b). Finally, trust-based patterns are expected to be associated with tasks characterized with high levels of uncertainty, together with high 
asset specificity and task interdependence, and low output measurability (Van der MeerKooistra and Vosselman 2000; Langfield-Smith and Smith 2003; Håkansson and Lind 2004).

In the light of the above considerations, the following proposition can be developed:

Proposition 1: In contracting-out relationships concerning the provision of public services, the type of controls (i.e. market-, hierarchy- and trust-based) put in place will be associated with different configurations of service characteristics (namely, asset specificity, task interdependence, uncertainty and output measurability).

The identified relationships and their expected signs are summarised in Table 1.

\section{Explanatory variables: Relationship characteristics}

The characteristics of the relationship (such as mode of delivery/goal congruence, political visibility and partner knowledge) between the parties involved in the public-service provision may be relevant not only in explaining contracting-out choices, but also in defining the types of controls subsequently set in place.

Previous contracting-out literature has identified the nature of the service provider (forprofit, non-profit, public) as a possible explanatory factor of the intensity of controls (Marvel and Marvel 2007, 2008; Van Slyke 2007). This variable has been alternatively called delivery mode (Marvel and Marvel 2007, 2008) or goal congruence (Van Slyke 2007; Provan and Milward 1995). These studies show that the controls put in place tend to have different intensities, with, in particular, much tighter controls used with for-profit 
providers, while public and non-profit providers show more aligned goals and behaviours (Marvel and Marvel 2007, 2008). We thus expect governmental and non-profit providers to be subject to lower levels of control than private for-profit companies. Similarly, high degrees of alignment between the public sector's and the provider's objectives (i.e. goal congruence) should result in less intense controls. At this stage, however, there is no definite evidence indicating the type of association between this variable and the type of controls, which calls for further investigation.

Looking at the few inter-organizational control studies on the topic, Cristofoli et al. (2010) suggest that high political visibility and high partner knowledge help explain a predominant bureaucratic model with a trust-based flavour. On the contrary, when political visibility and partner knowledge are low, bureaucratic models seem to be complemented by market-based mechanisms. The relationship between citizens and government is crucial since politicians are particularly sensitive to the general public's evaluation and potential criticism (Lioukas et al. 1993; Cristofoli et al. 2010). The attention paid by political bodies to certain services can explain the emphasis on developing more or less formal communication, frequent meetings and daily contacts. Literature has also shown that higher political visibility is associated with stronger intensity of controls (Lioukas et al. 1993). Finally, a few studies suggest that higher knowledge of the partner can result in either a reduced need for formal coordination or improved coordination (Dekker 2004; Cristofoli et al 2010).

From the above considerations, a second proposition follows:

Proposition 2: In contracting-out relationships concerning the provision of public services, the type of controls (i.e. market-, hierarchy- and trust-based) put in place will be associated 
with different relationship characteristics (namely, political visibility, delivery mode/goal congruence, partner knowledge).

Table 1 summarises the expected associations between relationship characteristics and types of control.

\section{Insert Table 1}

\section{Methods}

In order to carry out the research we conducted a survey for all Italian municipalities (510) of at least 20.000 inhabitants. We developed aquestionnaire, which was administered to the Chief Executive Officers (see Appendix 2, available online, data refer to 2008). The questionnaire was articulated in two sections: one dedicated to solid waste collection and the other to homecare services for elderly. These services were chosen in order to ensure diversity in the variables under consideration (Brown and Potoski 2003) ${ }^{2}$. We obtained a total of 91 responses $^{3}$, where $46 \%$ referred to solid waste collection and $54 \%$ to homecare for elderly.

To explore the proposed associations, we ran three separate linear regressions where against each type of control mechanism (market-based, hierarchy-based, trust-based), we regressed the independent variables previously discussed. The market-based pattern was measured adjusting Abernethy and Brownell's (1997) scale of output control (Crombach alpha 55\%). The hierarchy-based pattern drew on Abernethy and Brownell's (1997) scales

$$
\text { L }
$$

2 The governance of the elderly homecare services is overall more market-oriented than waste collection, as $96 \%$ of the providers are non-profit entities. 
of behavioural and accounting control. These items have been adjusted to take into consideration the extent of supervision over performed activities (Crombach alpha $76 \%$ ). Finally, Carson et al.'s (2006) scale was used for trust-based control (Crombach alpha $79.6 \%)$.

The independent variables are presented in Table 1, which specifies relevant literature, measures and scales used, together with their Crombach alpha for this study. It also shows the expected associations with the three types of controls (market-, hierarchy- and trustbased). In addition to service and relationship characteristics, we controlled for the geographical area (the North-South divide often being seen as relevant in Italian settings Anessi Pessina et al. 2008), the municipality's (in terms of population) and provider's (in terms of turnover) size, and the municipality's financial performance and political orientation.

The specification of the above model, including the regressors presented, is as follows:

Type of control $=\alpha+\beta_{1}$ Asset specificity $+\beta_{2}$ Task uncertainty $+\beta_{3}$ Task interdependence $+\beta_{4}$ Output measurability $+\beta_{5}$ Political visibility ${ }_{i}+\beta_{6}$ Delivery mode/goal congruence ${ }_{i}+\beta_{7}$ Old contract length $+\beta_{8}$ Turnover $+\beta_{9}$ Political orientation ${ }_{i}+\beta_{9}$ Population $+\beta_{10}$ Geographical area $+\beta 11$ Surplus/deficit $+\varepsilon$

Appendix 1 shows the correlation table for dependent and independent variables.

\section{Findings}

\section{Control patterns}

${ }^{3}$ In order to account for a non-response bias, we ran a two-sample t-test, using late respondents as surrogates for nonrespondents (Wallace and Mellor, 1988). The difference across responses was not statistically significant. 
Considering the descriptive statistics presented in Table 2, control patterns' mix and minimum and maximum scores relative to the three control types suggest that the trustbased mechanisms are the most present, followed by hierarchy- and market-based ones. Looking across services, while trust controls are still predominant (Table 3), hierarchybased controls are more present than market-based ones in the elderly homecare; vice-versa for waste collection.

\section{Insert Tables 2 and 3}

\section{Service and relationship characteristics}

In order to explore the variables associated with the different types of control (i.e. market-, hierarchy- and trust-based), three separate sets of linear regressions were performed (Tables 5, 6 and 7). As expected, the significance of the explanatory variables varies with the type of control adopted. Proposition 1 appears to hold for hierarchical and market-based patterns of control, but not for trust-based ones (Table 4). Interestingly, service characteristics appear to be significantly associated with the two former types of control, but not with the latter. Proposition 2, on the contrary, does not seem generally supported by our study, suggesting that relationship characteristics would tend not to be significantly associated with the type of control chosen (Table 4). Only political visibility appears to be significantly (at $1 \%$ ) related to market-based controls.

Insert Table 4

Explaining control mechanisms in contracting-out 
Looking more closely at the explanatory variables, market-based mechanisms are positively associated with political visibility (also representing the different types of services) and output measurability (both significant at $1 \%$ ), while negatively related to task uncertainty (at 5\% significance). Output measurability and task uncertainty are aligned with the prediction of the broader contracting-out and inter-organizational literatures. With respect to political visibility, the data show that waste collection services, which are the most visible to citizens, foster market-type controls. On the other hand, elderly homecare, although being characterized by governance systems based on the market, tends to display fewer market-control mechanisms. This finding contradicts our expectations and previous studies (Lioukas et al. 1993; Cristofoli et al. 2010).

Hierarchy-based mechanisms are more clearly explained by the identified variables, with an $\mathrm{R}^{2}$ of $54.37 \%$ defined by the significant (positive) association with asset specificity (10\%) and output measurability (1\%), and the negative relationship with the municipality's financial performance (significant at 5\%). These results are consistent with previous literature. A better organizational financial performance provides the basis for lower hierarchical control, thus less centralization and focus on processes (rather than final results) are required. It is also worth noting that service political visibility does not contribute to an explanation regarding the adoption of hierarchy-based controls.

Interestingly, trust-based controls do not seem to be explained by any of the variables that the traditional contracting-out and inter-organizational control literatures would propose. This suggests that while market and hierarchical controls can be better explained by service features, trust-based control patterns in the public sector may be more strongly influenced by the informality of the political processes and the role that these play in the decisions around the provision of public services. 
Finally, it is important to highlight that, contrary to expectations, the delivery mode/goal congruence (i.e. the fact that a private for-profit company is the provider) does not seem to influence the final choice of control mechanism. Similarly, geographical position (which strongly differentiates the economic and social background in Italy), municipality's political orientation, size of the municipality and of the provider, all do not seem to influence the choice of controls.

Insert Tables 5 to 7

\section{Control mechanisms and explanatory variables: an interpretation}

The findings suggest that it is not only important to consider the intensity of controls (as a limited number of studies had previously done), but also to distinguish across the types of controls that can be put in place. The analysis highlights that, in contracting-out relationships, market, hierarchy and trust controls display different intensities, can coexist and are explained by different variables.

The high score of trust-based mechanisms and the difficulty in explaining them may suggest that these controls are pervasive within public organizations and are strictly interwoven with the public nature of the services themselves. The strong presence of trustbased patterns entices two alternative explanations. On the one hand, very advanced or idiosyncratic configurations of relational/trust-based controls might be adopted, which are not fully explained by the variables suggested by the existing literature. On the other hand, "informal" channels of communication might be used to compensate for the lack of alternative monitoring tools. These dimensions are rarely captured by the variables traditionally used in the main literature and in research utilizing surveys and questionnaires. As a consequence, different factors, such as the presence of social or informal networks and 
the use of fiduciary appointments, may come into play. Trust probably provides the background against which other control choices are taken.

Our statistical model has its better predictive performance in the presence of hierarchybased controls, where, consistent with literature expectations, output measurability, asset specificity and financial performance prove relevant in explaining the choice of such mechanisms. However, delivery mode/goal congruence (Marvel and Marvel 2007, 2008; Hefetz and Warner 2012) and political visibility (Lioukas et al. 1993; Cristofoli et al. 2010) do not provide significant results. This is probably because hierarchical controls are those traditionally more established in the public sector (in our study, second only to trust-based ones), and, as a consequence, such mechanisms are always present in contracting-out relationships regardless of the type of service involved, its visibility and the nature of the provider (i.e. the delivery mode). The preference for hierarchical mechanisms is probably further strengthened by the traditional bureaucratic culture of the country under analysis, where the accomplishment of predefined rules is considered as the achievement of the result itself (Cristofoli et al. 2010). It is interesting to note that, despite recent calls for an increased attention towards political and contextual factors influencing public service management (Pollitt 2013; Cristofoli et al. 2010), we find that both political visibility and the contextual variables used as controls are not generally significant in explaining the choice between the two main mechanisms (trust and hierarchy-based controls).

The adoption of more recent market-based controls does not appear to replace hierarchical or trust-based ones. On the contrary, once trust and hierarchical bases have been laid, the results suggest that market controls also play a role, and selective choices are made when these mechanisms are deemed useful. They are associated with political visibility of the service (Lioukas et al. 1993; Cristofoli et al. 2010), its output measurability and task 
uncertainty (Van der Meer-Kooistra and Vosselman 2000; Langfield-Smith and Smith 2003; Håkansson and Lind 2004). This is in line with previous literature suggesting that the nature of the service itself matters in controlling and monitoring choices (Van Slyke 2007; Marvel and Marvel 2008).

In the presence of market-based control mechanisms, the type of service and its visibility are important not only to define the intensity of controls (as suggested by previous literature), but also the type of control exerted. This could have a twofold explanation. First, as a consequence of the managerial reforms that took place over the last two decades in the public sector, a greater emphasis has been put on the communication of results and output as a means of providing legitimation for public sector activities. Second, more politically visible services (such as waste collection) might require tighter overall controls because of their greater importance. This leads to a triangulation of different mechanisms (in addition to the more common trust- and hierarchy-based ones) to monitor the service and its provider. In short, trust-, hierarchy- and market-based mechanisms represent "layers" of control, which, far from being mutually exclusive, tend to complement each other, perhaps mirroring the development of control systems in the wider public sector. This coexistence might reflect, on the one hand, the current state of the art of control mechanisms in the public sector, which could be considered as still evolving. Furthermore, it could also be the consequence of the "liability of newness" of the mechanisms themselves, where decision makers tend to stick to the practices they know better, adding new types of controls when necessary.

Overall, the scant relevance of a number of variables proposed by the extant literature could be explained by the limited consideration that municipalities and/or their units have given to public-service providers' monitoring and control devices so far. This attitude 
might bring about a relative weakness in control systems' design, which, in turn, may also account for the low variance across the different delivery modes (majority of non-profits in elderly homecare, majority of public-sector providers in waste collection). This interpretation is consistent with Van Slyke's (2007) finding of a lack of monitoring variation in social-service providers, accompanied by a general underdevelopment of the systems.

The above findings also confirm the importance of looking not only at the governance modes, but also at the control practices adopted in contracting-out relationships. A paradox seems to emerge where, although the governance structure of the elderly homecare sector is market-oriented and based on accreditation systems (relying on the externalisation of the service to private non-profit providers in the majority of the cases), market-based controls are significantly more present for waste collection (in the provision of which public-owned organizations are instead more often involved). This confirms that market-based controls are not necessarily tied to the mode of governance adopted, and therefore control practices can be of a different nature to the organizational forms chosen for public-service provision (Spekle 2001; Caglio and Ditillo 2008a).

\section{Conclusions}

Public-service contracting-out has often been accompanied by a strong academic focus on the emergence of new governance forms, and a major neglect of the processes and practices through which these contracted-out services are controlled and monitored. Trying to fill this gap, this paper explored the mechanisms set in place to control the provision of different public services at the municipal level. In particular, bringing together variables so far investigated separately in the inter-organizational control and contracting-out literatures, we 
explored whether the variables traditionally used in these studies have explanatory potential with reference to control choices of contracted-out services.

We find that service characteristics are more effective in explaining market- and hierarchybased mechanisms than relationship characteristics. Moreover, trust-, hierarchy- and market-based mechanisms seem to require different explanatory models. Trust-based controls, in particular, are the most widespread, but cannot be explained by the contractingout and inter-organizational variables traditionally used. This finding calls for further investigation of both the types of trust-based controls in use and the effectiveness of these monitoring systems. It is of note that market-based controls are not necessarily tied to the form of governance adopted. Finally, different from expectations (Marvel and Marvel 2007, 2008), mode of delivery and goal congruence do not appear to influence significantly the type of control adopted.

This paper's contribution is twofold. First, we assessed the explanatory potential of transaction-cost variables with reference to control choices, rather than to contracting-out choices as most of the literature had done before. Second, while the little literature on the control of contracted-out public services has mostly focused on the intensity of the controls put in place, we also took into consideration their type (hierarchy, market and trust), integrating the contracting-out with inter-organizational control literatures and showing that not all variables are relevant in contracting-out relationships.

The study calls for further research on services with different characteristics. The importance of trust-based controls and the difficulty in explaining their adoption with respect to traditional variables (mainly drawn on economic and control studies) suggest that additional studies are needed to explore the role of other variables, such as political and informal factors, in defining the type and the intensity of the controls used between the 
public sector and public-service providers. The findings highlight the importance of distinguishing between the three different types of control, as market and hierarchical mechanisms appear more influenced by variables linked to managerial rationality, while trust-based ones might relate more to expressions of political rationality. Future studies might devote more attention towards the political and contextual factors affecting publicservice management (Pollitt 2013) ${ }^{4}$, which cannot simply be grasped through quantitative analysis. Understanding the dynamics and complexities of contracting-out requires the accumulation of knowledge through a combination of multidisciplinary and theoretical approaches, as well as mixed methods of analysis. Consistent with this view, while we conducted a survey, studying informal processes of control might require more participative research methods, such as interviews, direct observations and ethnographic studies.

From a managerial perspective, our results suggest that public managers need to be aware of the different types of controls available, and that they should consider the appropriateness of the controls used in managing relationships with the service providers, taking into consideration both service and relationship characteristics. The current pervasiveness of trust-based mechanisms also points to the need for the development of managerial competences and skills, such as communication, negotiation and networking, together with the strengthening of transparency mechanisms in place between the public sector and service providers. From a policy perspective, policy makers often tend to focus on the design of public-service governance modes, neglecting the related control mechanisms. This paper also highlights the necessity for regulators to place more emphasis on encouraging the development of monitoring systems for public services, especially for those contracted-out. In doing so, they should adopt an integrated and holistic view of the L

${ }^{4} \mathrm{We}$ are indebted to one of the reviewers for this further perspective. 
possible control systems and pay particular attention to trust-based mechanisms, where, the danger exists, that, in pursuing a desire for informality, possible threats to public accountability are obscured. Moreover, they should avoid the usual "one-fits-all" approach, as the intensity and types of control should reflect the features of the services involved. Finally, they should be aware that governance modes adopted and the relative control mechanisms do not necessarily coincide or align, hence the need to choose appropriate control mechanisms and go beyond the selection of packaged stereotypes. 


\section{References}

Abernethy, M. and P. Brownell. 1997. 'Management Control Systems in Research and Development Organizations: the Role of Accounting, Behavior and Personnel Controls', Accounting, Organizations \& Society, 22,3/4, 233-248.

Albalate, D., Bel, G., Geddes, R., 2013.'Recovery Risk and Labor Costs in Public-Private

Partnerships: Contractual Choice in the US Water Industry', Local Government Studies, $39: 3,332-351$.

Anessi Pessina, E., G. Nasi and I. Steccolini .2008. 'Accounting Reforms: Determinants of Local Governments' Choices', Financial Accountability \& Management, 24,3, 321-42.

Bel, G. and M. Warner. 2008. 'Challenging issues in local privatization', Environment and Planning : Government and Policy, 26, 1, 104-109.

Bensaou, B. and V. Venkatraman. 1995. 'Configurations of Interorganizational Relationships: A Comparison Between U.S. and Japanese Automakers', Management Science, 41,9, 1471-1493.

Bevir, M. and R.A.W. Rhodes. 2003. Interpreting British Governance. London: Routledge.

Bovaird, T. 2006. 'Developing New Forms of Partnership With the 'Market' in the Procurement of Public Services', Public Administration, 84,1, 81-102.

Brown, M. and J. Brudney . 1998. 'A Smarter, Better, Faster, and Cheaper Government: Contracting and Geographic Information Systems', Public Administration Review, 58,4, 335-345.

Brown, T., M. Potoski, and D. Van Slyke. 2006. 'Managing Public Servicing Contracts: Aligning Values, Institutions and Markets', Public Administration Review, 66,3, 323-331. 
Brown, T. and M. Potoski. 2003. 'Transaction Costs and Institutional Explanations for Government Service Production Decisions', Journal of Public Administration Research and Theory, 13, 441-468.

Caglio, A. and A. Ditillo. 2008a. 'A review and discussion of management control in interfirm relationships: Achievements and future directions', Accounting, Organizations and Society, 33,7/8, 865-898.

Caglio, A. and A. Ditillo. 2008b. Controlling Collaboration between Firms. How to Build and Maintain Successful Relationships with External Partners. Oxford: Elsevier.

Carson, S., A. Madhok and T. Wu. 2006. 'Uncertainty, opportunism and governance: the effects of volatility and ambiguity on formal and relational contracting', Academy of Management Journal, 49,5, 1058-77.

Cristofoli, D., A. Ditillo, M. Liguori, M. Sicilia and I. Steccolini .2010. 'Do environmental and task characteristics matter in the control of externalized local public services? Unveiling the relevance of party characteristics and citizens' offstage voice', Accounting, Auditing \& Accountability Journal, 23, 3, 350-372.

Das, T. K., and Teng, B. S. 1998 'Between trust and control: developing confidence in partner cooperation alliances', Academy of Management Review, 23, 491-512.

Davis, P. 2007. 'The Effectiveness of Relational Contracting in a Temporary Public Organization: Intensive Collaboration between an English Local Authority and Private Contractors', Public Administration, 85,2, 383-404.

Dekker, H. C. 2004. 'Control of inter-organizational relationships: evidence on appropriation concerns and coordination requirements', Accounting, Organizations and Society, 29, 27-49. 
Donahue, J. 1989. The Privatization Decision: Public Ends, Private Means. New York: Basic Books.

Fernandez, S. 2007. 'What works best when contracting for services? An analysis of contracting performance at the local level in the US', Public Administration, 85,4.

Ferris, J. and E. Graddy .1991. 'Production Costs, Transaction Costs, and Local Government Contractor Choice', Economic Inquiry, 29, 541-54.

Hakansson, H. and J. Lind .2004. 'Accounting and network coordination', Accounting, Organizations and Society, 29, 51-72.

Hefetz, A. and M. Warner .2012. 'Contracting or Public Delivery? The Importance of Service, Market, and Management Characteristics', Journal of Public Administration Theory and Practice, 22,2, 289-317.

Jensen, M. and W. Meckling .1996. 'Theory of the firm: Managerial behavior, agency costs, and ownership structure', in P. J. Buckley and J. Michie (eds), Firms, organizations, and contracts: A reader in industrial organization. Oxford, NY: Oxford Univ. Press, pp. $103-167$.

Johnston, J. and B. S. Romzek .1999. 'Contracting and Accountability in State Medicaid Reform: Rhetoric, Theories, and Reality', Public Administration Review, 59,5, 383-399.

Kettl, D. 1993. Sharing Power: Public Governance and Private Markets. Washington, DC: Brookings Institution.

Langfield-Smith, K. and D. Smith .2003. 'Management control systems and trust in outsourcing relationships', Management Accounting Research, 14,3, 281-307. 
Lioukas, S., D. Bourantas, and V. Papadakis .1993. 'Managerial Autonomy Of StateOwned Enterprises: Determining Factors', Organization Science, 4, 4, 645-666.

Malatesta, D. and C. Smith .2014, 'Designing Contracts for Complex Services', Public Aministration, doi: 10.1111/padm.12004.

Marvel, M. and H. Marvel .2008. 'Government-to-Government Contracting: Stewardship, Agency, and Substitution', International Public Management Journal, 11,2, 171-192.

Marvel, M. and H. Marvel .2007. 'Outsourcing Oversight: A Comparison of Monitoring for In-House and Contracted Services', Public Administration Review. 67, 3, 521-530.

Miller, P., L. Kurunmaki and T. O’Leary. 2008. ;Accounting, Hybrids and the Management of Risk', Accounting, Organizations and Society, 33, 942-967.

Milward, H. and K. Provan .2000. 'Governing the Hollow State', Journal of Public Administration Research and Theory, 10, 2, 359-380.

Pollitt, C. 2013. Context in Public Policy and Management: The Missing Link?. Cheltenham: Edward Elgar Publishing.

Provan, K. and H. Milward .1995. 'A Preliminary Theory of Network Effectiveness: A Comparative Study of Four Community Mental Health Systems', Administrative Science Quarterly, 40,1, 1-33.

Romzek, B. and J. Johnston .2002. 'Contract Implementation and Management Effectiveness: A Preliminary Model', Journal of Public Management Research and Theory, $12,3,423-53$.

Sclar, E. 2000. You Don't Always Get What You Pay For: The Economics of Privatization. Ithaca, NY: Cornell University Press. 
Spekle, R.2001. 'Explaining management control structure variety: a transaction cost economics perspective', Accounting, Organizations and Society, 26,4, 419-441.

Van der Meer-Kooistra, J. and E. G. Vosselman .2000. 'Management control of interfirm transactional relationships: the case of industrial renovation and maintenance', Accounting, Organizations and Society, 25, 51-77.

Van Slyke, D.2003. 'The Mithology of Privatization in Contracting for Social Services', Public Administration Review, 63,3, 296-315.

Van Slyke, D. 2007. 'Agent or Stewards: Using Theory to Understand the GovernmentNonprofit Social Service Contracting Relationship', Journal of Public Administration Research \& Theory, 17, 2, 157-187.

Wallace, R.S. and C. Mellor .1988. 'Nonresponse bias in mail accounting surveys: A pedagogical note', British Accounting Review, 20, 131-139.

Warner, M. and A. Hefetz .2008. 'Managing Markets for Public Service: The Role of Mixed Public-Private Delivery of City Services', Public Administration Review, 68,1, 155166.

Williamson, O. 1981. 'The Economics of Organization: The Transaction Cost Approach', American Journal of Sociology, 87, 548-577. 


\section{Tables}

Table 1 - Independent variables: literature, measures, expectations

\begin{tabular}{|c|c|c|c|c|c|}
\hline \multirow[t]{2}{*}{ Independent variables } & \multirow[t]{2}{*}{ References } & \multirow[t]{2}{*}{ Measures } & \multicolumn{3}{|c|}{ Expectations } \\
\hline & & & Market- based & $\begin{array}{c}\text { Hierarchy- } \\
\text { based }\end{array}$ & Trust-based \\
\hline \multicolumn{6}{|l|}{ Service characteristics } \\
\hline Asset specificity & $\begin{array}{l}\text { Ferris and Graddy (1991) } \\
\text { Van der Meer-Kooistra and } \\
\text { Vosselman (2000) } \\
\text { Milward and Provan (2000) } \\
\text { Brown and Potoski (2003) } \\
\text { Langfield-Smith and Smith (2003) } \\
\text { Håkansson and Lind (2004) } \\
\text { Caglio and Ditillo (2008a, 2008b) }\end{array}$ & $\begin{array}{l}\text { Fernandez's (2007) Likert } \\
\text { scale, measuring the extent to } \\
\text { which the investments made to } \\
\text { support a particular } \\
\text { transaction have a higher value } \\
\text { to that transaction than they } \\
\text { would have if they were } \\
\text { redeployed for any other } \\
\text { purpose. } \\
\text { Crombach alpha } 60 \%\end{array}$ & Low & Moderate & High \\
\hline Task uncertainty & $\begin{array}{l}\text { Ferris and Graddy (1991) } \\
\text { Van der Meer-Kooistra and } \\
\text { Vosselman (2000) } \\
\text { Milward and Provan (2000) } \\
\text { Brown and Potoski (2003) } \\
\text { Langfield-Smith and Smith (2003) } \\
\text { Håkansson and Lind (2004) } \\
\text { Caglio and Ditillo (2008a, 2008b) }\end{array}$ & $\begin{array}{l}\text { Abernethy and Brownell's (1997) } \\
\text { scale, used to measure, in } \\
\text { five-point fully anchored form, } \\
\text { the level of task analysability } \\
\text { that may derive from the } \\
\text { execution of the task } \\
\text { Crombach alpha } 81.2 \%\end{array}$ & LOW & Moderate & High \\
\hline Task interdependence & $\begin{array}{l}\text { Ferris and Graddy (1991) } \\
\text { Van der Meer-Kooistra and } \\
\text { Vosselman (2000) } \\
\text { Milward and Provan (2000) } \\
\text { Brown and Potoski (2003) } \\
\text { Langfield-Smith and Smith (2003) } \\
\text { Lakansson and Lind (2004) } \\
\text { Caglio and Ditillo (2008a, 2008b) }\end{array}$ & $\begin{array}{l}\text { Ben Bensaou and Venkat } \\
\text { Venkatraman (1995)'s scale. } \\
\text { Respondents were asked to } \\
\text { indicate on a } 5-i t e m \text { scale the } \\
\text { extent to which the service } \\
\text { providers rely on the } \\
\text { municipality to start, progress } \\
\text { and complete their activities. } \\
\text { Crombach alpha } 75.2 \%\end{array}$ & Low & Moderate & High \\
\hline Output measurability & $\begin{array}{l}\text { Ferris and Graddy (1991) } \\
\text { Van der Meer-Kooistra and } \\
\text { Vosselman (2000) } \\
\text { Milward and Provan (2000) } \\
\text { Brown and Potoski (2003) } \\
\text { Langfield-Smith and Smith (2003) } \\
\text { Håkansson and Lind (2004) } \\
\text { Caglio and Ditillo (2008a, 2008b) }\end{array}$ & $\begin{array}{l}\text { Trevor Brown and Matthew } \\
\text { Potoski (2005)' s scale, using } \\
\text { a five-point fully anchored } \\
\text { instrument to measure the } \\
\text { measurability of outputs. } \\
\text { Crombach alpha } 78.6 \%\end{array}$ & High & Low & Low \\
\hline \multicolumn{6}{|c|}{ Relationship characteristics } \\
\hline Political visibility & $\begin{array}{l}\text { Lioukas et al (1993) } \\
\text { Cristofoli et al (2011) }\end{array}$ & $\begin{array}{l}\text { As a proxy for political } \\
\text { visibility we used the number }\end{array}$ & Low & Moderate & High \\
\hline
\end{tabular}

\footnotetext{
${ }^{5}$ Summed scores for the set of items loading on each factor were used as opposed to factor scores, because of the conventional caution on the instability of factor loading solutions.
} 


\begin{tabular}{|c|c|c|c|c|c|}
\hline & Hefetz and Warner (2012) & $\begin{array}{l}\text { of final users for the } \\
\text { services, higher for waste } \\
\text { collection (pol_vis=1) and } \\
\text { lower for homecare services } \\
\text { pol_vis=0). }\end{array}$ & & & \\
\hline $\begin{array}{l}\text { Delivery mode/ goal } \\
\text { congruence }\end{array}$ & $\begin{array}{l}\text { Provan and Milward (1995) } \\
\text { Van Slyke (2007) } \\
\text { Marvel and Marvel (2007, 2008) }\end{array}$ & $\begin{array}{l}\text { Drawing on Marvel and Marvel } \\
\text { (2007, 2008) the delivery mode } \\
\text { was defined in terms of the } \\
\text { main dichotomy in provider's } \\
\text { ownership, distinguishing } \\
\text { across private for-profit } \\
\text { (delivery mode/goal-congr=1) } \\
\text { vs. non-profit entities (both } \\
\text { public and private, delivery } \\
\text { mode/goal_congr=0). }\end{array}$ & No expectation & $\begin{array}{c}\text { No } \\
\text { expectation }\end{array}$ & $\begin{array}{c}\text { No } \\
\text { expectation }\end{array}$ \\
\hline Partner knowledge & Cristofoli et al (2011) & $\begin{array}{l}\text { Length of previous contract } \\
\text { (days) }\end{array}$ & Low & Moderate & High \\
\hline Controls & & & & & \\
\hline Provider's size & & $\begin{array}{l}\text { Provider's turnover (thousands } \\
\text { of Euros) }\end{array}$ & No expectation & $\begin{array}{c}\text { No } \\
\text { expectation }\end{array}$ & $\begin{array}{c}\text { No } \\
\text { expectation }\end{array}$ \\
\hline Political orientation & $\begin{array}{l}\text { Hefetz and Warner (2012) } \\
\text { Albalate et al. (2013) }\end{array}$ & $\begin{array}{l}\text { Municipality's council } \\
\text { political orientation in 2008: } \\
\text { Centre-right (0) } \\
\text { Centre-left (1) }\end{array}$ & No expectation & $\begin{array}{c}\text { No } \\
\text { expectation }\end{array}$ & $\begin{array}{c}\text { No } \\
\text { expectation }\end{array}$ \\
\hline Municipality's size & Albalate et al. (2013) & (ln) population size & No expectation & $\begin{array}{c}\text { No } \\
\text { expectation }\end{array}$ & $\begin{array}{c}\text { No } \\
\text { expectation }\end{array}$ \\
\hline Geographical position & Hefetz and Warner (2012) & $\begin{array}{ll}\text { North-centre } & (1) \\
\text { South-centre } & (0)\end{array}$ & No expectation & $\begin{array}{c}\text { No } \\
\text { expectation }\end{array}$ & $\begin{array}{c}\text { No } \\
\text { expectation }\end{array}$ \\
\hline Financial performance & Hefetz and Warner (2012) & $\begin{array}{l}\text { municipality's surplus/deficit } \\
\text { (thousands of Euros) }\end{array}$ & No expectation & $\begin{array}{c}\text { No } \\
\text { expectation }\end{array}$ & $\begin{array}{c}\text { No } \\
\text { expectation }\end{array}$ \\
\hline
\end{tabular}


Table 2 -Descriptive statistics

\begin{tabular}{|c|c|c|c|c|c|}
\hline Variable & Obs & Mean & Std. Dev. & Min & $\operatorname{Max}$ \\
\hline $\begin{array}{l}\text { Market } \\
\text { Hierarchy } \\
\text { Trust } \\
\text { Turnover } \\
\text { Political } \\
\text { visibility }\end{array}$ & $\begin{array}{l}87 \\
91 \\
90 \\
62 \\
91\end{array}$ & $\begin{array}{c}2.258621 \\
3.09652 \\
3.693915 \\
2.01 e+08 \\
.4615385\end{array}$ & $\begin{array}{r}.7824623 \\
.6681766 \\
.5279828 \\
9.04 e+08 \\
.5012804\end{array}$ & $\begin{array}{r}1 \\
1.333333 \\
2.142857 \\
84162 \\
0\end{array}$ & $\begin{array}{r}4 \\
4.5 \\
4.857143 \\
6.09 e+09 \\
1\end{array}$ \\
\hline $\begin{array}{l}\text { Asset } \\
\text { specificity } \\
\text { Output } \\
\text { measurability } \\
\text { Task } \\
\text { uncertainty } \\
\text { Task } \\
\text { interdependence } \\
\text { Population(ln) }\end{array}$ & $\begin{array}{l}91 \\
91 \\
91 \\
91 \\
91\end{array}$ & $\begin{array}{l}3.045788 \\
3.586264 \\
3.635531 \\
3.142857 \\
11.47022 \\
\end{array}$ & $\begin{array}{r}.5098208 \\
.5877011 \\
.4248242 \\
.7406085 \\
.8946997 \\
\end{array}$ & $\begin{array}{r}1.333333 \\
2 \\
2.555556 \\
1 \\
9.939674 \\
\end{array}$ & $\begin{array}{r}4.5 \\
4.8 \\
4.666667 \\
4.666667 \\
14.07759 \\
\end{array}$ \\
\hline $\begin{array}{l}\text { Old contract } \\
\text { length } \\
\text { Political } \\
\text { orientation } \\
\text { Geographical } \\
\text { area } \\
\text { Surplus/deficit } \\
\text { Delivery mode/ } \\
\text { goal congruence }\end{array}$ & $\begin{array}{l}79 \\
91 \\
91 \\
91 \\
91 \\
84\end{array}$ & $\begin{array}{l}68.56962 \\
.6153846 \\
.5714286 \\
2.14 e+07 \\
2.190476\end{array}$ & $\begin{array}{l}109.6675 \\
.4891996 \\
.4976134 \\
6.99 e+07 \\
.8981399\end{array}$ & $\begin{array}{r}3 \\
0 \\
0 \\
-4778352 \\
1\end{array}$ & 4.6 \\
\hline
\end{tabular}


Table 3 - Descriptive statistics by service

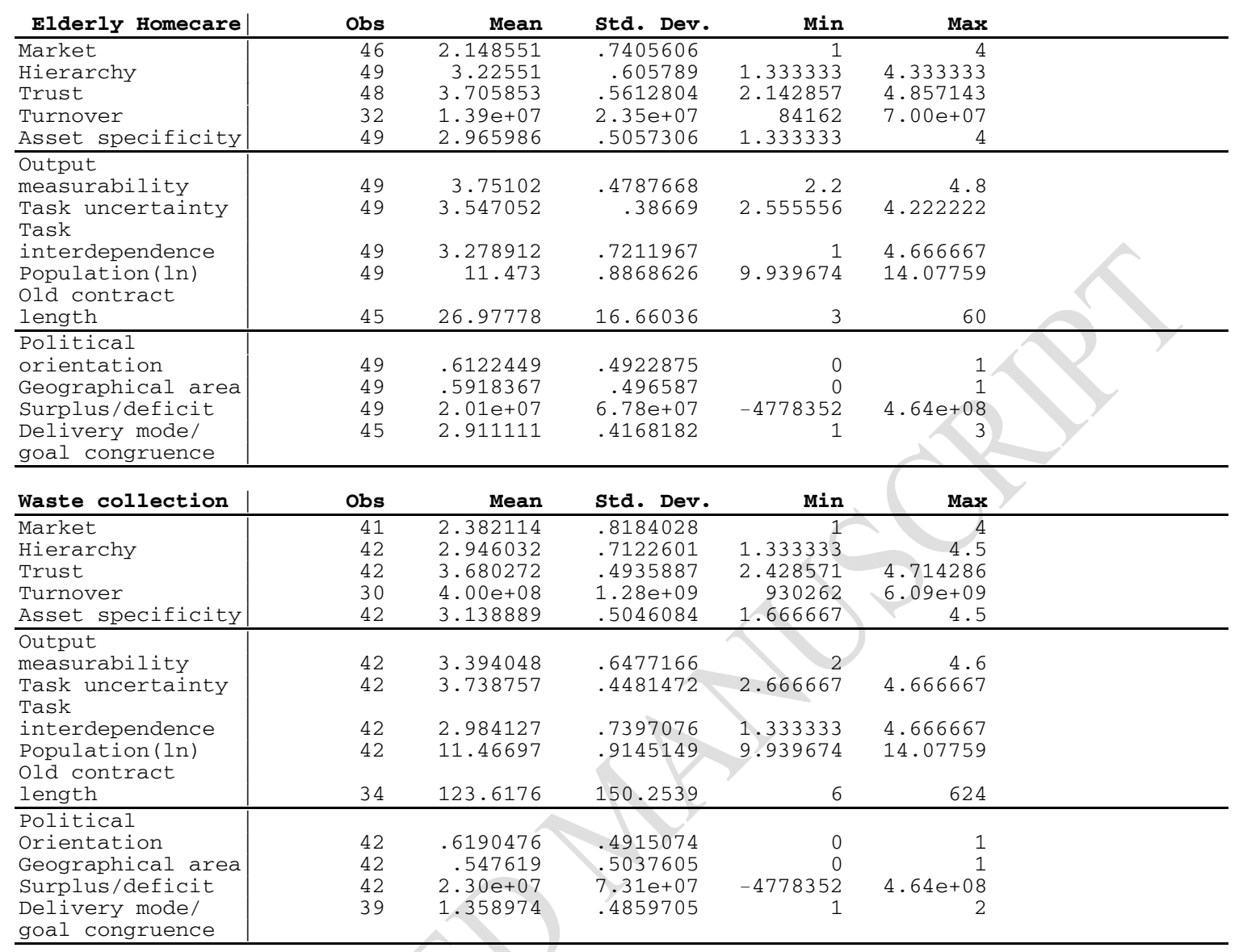


Table 4 -Findings: expected and actual associations

\begin{tabular}{|c|c|c|c|c|c|c|c|}
\hline & Type of control/Dependent & \multicolumn{2}{|c|}{ Market- based } & \multicolumn{2}{|c|}{ Hierarchy-based } & \multicolumn{2}{|c|}{ Trust-based } \\
\hline & Independent variables & $\begin{array}{l}\text { Expected } \\
\text { sign }\end{array}$ & Findings & $\begin{array}{l}\text { Expected } \\
\text { sign }\end{array}$ & Findings & $\begin{array}{l}\text { Expected } \\
\text { sign }\end{array}$ & Findings \\
\hline \multicolumn{8}{|c|}{ Service characteristics } \\
\hline \multirow{4}{*}{$\begin{array}{c}\text { Proposition } \\
1\end{array}$} & Asset specificity & Low & - & Moderate & Confirmed & High & - \\
\hline & Task uncertainty & Low & Confirmed & Moderate & & High & - \\
\hline & Task interdependence & Low & - & Moderate & $-{ }_{-}-$ & High & - \\
\hline & Output measurability & High & Confirmed & Low & Confirmed & Low & - \\
\hline Relationship & characteristics & & & & & & \\
\hline \multirow{3}{*}{$\begin{array}{c}\text { Proposition } \\
2\end{array}$} & Political visibility & Low & $\begin{array}{c}\text { High } \\
\text { (Contradicted) }\end{array}$ & Moderate & - & High & - \\
\hline & Delivery mode/ goal congruence & $\begin{array}{c}\text { No } \\
\text { expectation }\end{array}$ & 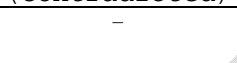 & $\begin{array}{c}\text { No } \\
\text { pectation }\end{array}$ & - & $\begin{array}{c}\text { No } \\
\text { expectation }\end{array}$ & - \\
\hline & Partner knowledge & Low & - & Moderate & - & High & - \\
\hline \multicolumn{8}{|l|}{ Controls } \\
\hline & Provider's size & $\begin{array}{c}\text { No } \\
\text { expectation }\end{array}$ & - & $\begin{array}{c}\text { No } \\
\text { expectation }\end{array}$ & - & $\begin{array}{c}\text { No } \\
\text { expectation }\end{array}$ & - \\
\hline & Political orientation & $\begin{array}{c}\text { No } \\
\text { expectation }\end{array}$ & & $\begin{array}{c}\text { No } \\
\text { expectation }\end{array}$ & - & $\begin{array}{c}\text { No } \\
\text { expectation }\end{array}$ & - \\
\hline & Geographical position & $\begin{array}{c}\text { No } \\
\text { expectation }\end{array}$ & - & $\begin{array}{c}\text { No } \\
\text { expectation }\end{array}$ & - & $\begin{array}{c}\text { No } \\
\text { expectation }\end{array}$ & - \\
\hline & Financial performance & $\begin{array}{c}\text { No } \\
\text { expectation }\end{array}$ & - & $\begin{array}{c}\text { No } \\
\text { expectation }\end{array}$ & High & $\begin{array}{c}\text { No } \\
\text { expectation }\end{array}$ & - \\
\hline
\end{tabular}


Table 5 - Regression results for market-based control

\begin{tabular}{|c|c|c|c|}
\hline Source & SS & $d f$ & MS \\
\hline $\begin{array}{r}\text { Model } \\
\text { Residual }\end{array}$ & $\begin{array}{l}10.5925477 \\
17.8911126\end{array}$ & $\begin{array}{l}12 \\
38\end{array}$ & $\begin{array}{r}88271231 \\
.470818753\end{array}$ \\
\hline Total & 28.4836603 & 50 & .569673206 \\
\hline
\end{tabular}

$$
\begin{array}{lrr}
\text { Number of obs } & = & 51 \\
\text { F }(12, \quad 38) & = & 1.87 \\
\text { Prob }>\text { F } & =0.0701 \\
\text { R-squared } & = & 0.3719 \\
\text { Adj R-squared } & = & 0.1735 \\
\text { Root MSE } & = & .68616
\end{array}
$$

\begin{tabular}{|c|c|c|c|c|c|c|}
\hline Market & Coef. & Std. Err. & t & $P>|t|$ & [95\% Conf. & Interval] \\
\hline $\begin{array}{l}\text { Turnover } \\
\text { Political }\end{array}$ & $-7.81 e-11$ & $2.00 e-10$ & -0.39 & 0.698 & $-4.83 e-10$ & $3.26 e-10$ \\
\hline visibility (1) & .9077998 & .3139598 & 2.89 & 0.006 & .2722214 & 1.543378 \\
\hline Asset specificity & -.1217351 & .191822 & -0.63 & 0.529 & -.5100585 & .2665883 \\
\hline Output measurability & .8294338 & .2297293 & 3.61 & 0.001 & .3643711 & 1.294497 \\
\hline Task uncertainty & -.5577926 & .2706411 & -2.06 & 0.046 & -1.105677 & .0099083 \\
\hline Task interdependence & -.0744968 & .1559565 & -0.48 & 0.636 & -.3902142 & .2412205 \\
\hline Population(ln) & .0353652 & .1408685 & 0.25 & 0.803 & -.2498082 & .3205386 \\
\hline $\begin{array}{l}\text { Old contract length } \\
\text { Political }\end{array}$ & -.0008338 & .001422 & -0.59 & 0.561 & -.0037125 & 449 \\
\hline orientation (1) & -.2130474 & .271713 & -0.78 & 0.438 & -.7631016 & .3370068 \\
\hline Geographical area (1) & .0086965 & .2768335 & 0.03 & 0.975 & -.5517236 & .5691165 \\
\hline Surplus/deficit & $-2.63 e-09$ & $1.82 \mathrm{e}-09$ & -1.44 & 0.157 & $-6.33 e-09$ & $1.06 e-09$ \\
\hline Delivery mode/ & -.5588987 & .4039567 & -1.38 & 0.175 & -1.376666 & .2588688 \\
\hline cons & 1.262319 & 1.983928 & 0.64 & 0.528 & -2.753933 & 5.27857 \\
\hline
\end{tabular}

\begin{tabular}{|c|c|c|c|c|c|c|}
\hline Hierarchy & Coef. & Std. Err. & $t$ & $\mathrm{P}>|\mathrm{t}|$ & [95\% Conf. & Interval] \\
\hline $\begin{array}{l}\text { Turnover } \\
\text { Political }\end{array}$ & $.83 e-10$ & $1.50 e-10$ & -1.22 & 0.231 & $-4.87 e-10$ & $1.21 e-10$ \\
\hline visibility (1) & .0962652 & .2356317 & -0.41 & 0.685 & -.5728753 & .3803448 \\
\hline Asset specificity & .2578674 & .1426553 & 1.81 & 0.078 & -.0306801 & .5464149 \\
\hline Output measurability & 8085447 & .1730135 & 4.67 & 0.000 & .458592 & 1.158498 \\
\hline Task uncertainty & 2529798 & .2045268 & -1.24 & 0.224 & -.6666742 & .1607147 \\
\hline Task interdependence & .045219 & .1142439 & 0.40 & 0.694 & -.185861 & .2762991 \\
\hline Population (ln) & .1748687 & .1049856 & 1.67 & 0.104 & -.0374847 & .387222 \\
\hline $\begin{array}{l}\text { Old contract len } \\
\text { Political }\end{array}$ & .0003596 & .0010756 & 0.33 & 0.740 & -.0018159 & .0025351 \\
\hline orientation (1) & -.0103947 & .1997981 & -0.05 & 0.959 & -.4145244 & .3937351 \\
\hline Geographical area (1) & 60648 & .1993199 & 1.64 & 0.110 & -.0770977 & .7292274 \\
\hline Surplus/deficit & $-2.82 e-09$ & $1.36 e-09$ & -2.07 & 0.045 & $-5.58 e-09$ & $-5.97 e-11$ \\
\hline $\begin{array}{l}\text { Delivery mode/ } \\
\text { goal congruence (1) }\end{array}$ & .2248121 & .3051717 & 0.74 & 0.466 & -.392456 & .8420801 \\
\hline cons & -1.97291 & 1.47505 & -1.34 & 0.189 & -4.956481 & 1.010661 \\
\hline
\end{tabular}

Table 6 - Regression results for hierarchy-based control

\begin{tabular}{r|rrr} 
Source & SS & df & MS \\
Model & 12.5171545 & 12 & 1.0430962 \\
Residual & 10.5062656 & 39 & .269391426 \\
--10 & 51 & .451439609
\end{tabular}

$$
\begin{array}{lrr}
\text { Number of obs } & = & 52 \\
\text { F (12, 39) } & = & 3.87 \\
\text { Prob }>\text { F } & 0.0006 \\
\text { R-squared } & = & 0.5437 \\
\text { Adj R-squared } & = & 0.4033 \\
\text { Root MSE } & = & .51903
\end{array}
$$


Table 7 - Regression results for trust-based control

\begin{tabular}{r|rrr} 
Source & SS & df & MS \\
Model & 1.88783483 & 12 & .157319569 \\
Residual & 10.794661 & 39 & .276786181 \\
-12.6824959 & 51 & .24867639
\end{tabular}

$\begin{array}{llr}\text { Number of obs } & & 52 \\ \mathrm{~F}(12, & 39) & 0.57 \\ \text { Prob }>\text { F } & = & 0.8537 \\ \text { R-squared } & = & 0.1489 \\ \text { Adj R-squared } & = & -0.1130 \\ \text { Root MSE } & = & .5261\end{array}$

\begin{tabular}{|c|c|c|c|c|c|c|}
\hline Trust & Coef. & Std. Err. & t & $P>|t|$ & [95\% Conf. & Interval] \\
\hline $\begin{array}{l}\text { Turnover } \\
\text { Political }\end{array}$ & $6.40 e-11$ & $1.52 \mathrm{e}-10$ & 0.42 & 0.677 & $-2.44 e-10$ & $3.72 \mathrm{e}-10$ \\
\hline visibility (1) & -.0178381 & .2388438 & -0.07 & 0.941 & -.5009453 & .4652691 \\
\hline Asset specificity & .1462505 & .1445999 & 1.01 & 0.318 & -.1462304 & .4387315 \\
\hline Output measurability & .0203358 & .175372 & 0.12 & 0.908 & -.3343875 & .3750591 \\
\hline Task uncertainty & -.0527861 & .2073149 & -0.25 & 0.800 & -.4721201 & .3665478 \\
\hline Task interdependence & -.0281508 & .1158013 & -0.24 & 0.809 & -.262381 & \\
\hline Population ( In) & .0316492 & .1064167 & 0.30 & 0.768 & -.1835989 & .2468973 \\
\hline old contract length & .0008672 & .0010902 & 0.80 & 0.431 & -.001338 & .0030724 \\
\hline Political orientation & -.1748368 & .2025217 & -0.86 & 0.393 & -.5844756 & .2348021 \\
\hline Geographical area (1) & -.0552689 & .202037 & -0.27 & 0.786 & -.4639274 & .3533895 \\
\hline Surplus/deficit & $-2.28 e-09$ & $1.38 e-09$ & -1.65 & 0.107 & $-5.07 e-09$ & $5.19 e-10$ \\
\hline Delivery mode/ & -.1236682 & .3093318 & -0.40 & 0.691 & & .5020145 \\
\hline cons & 3.247743 & 1.495158 & 2.17 & 0.036 & .2234999 & 6.2719 \\
\hline
\end{tabular}




\section{Appendix 1}

\section{Correlation table}

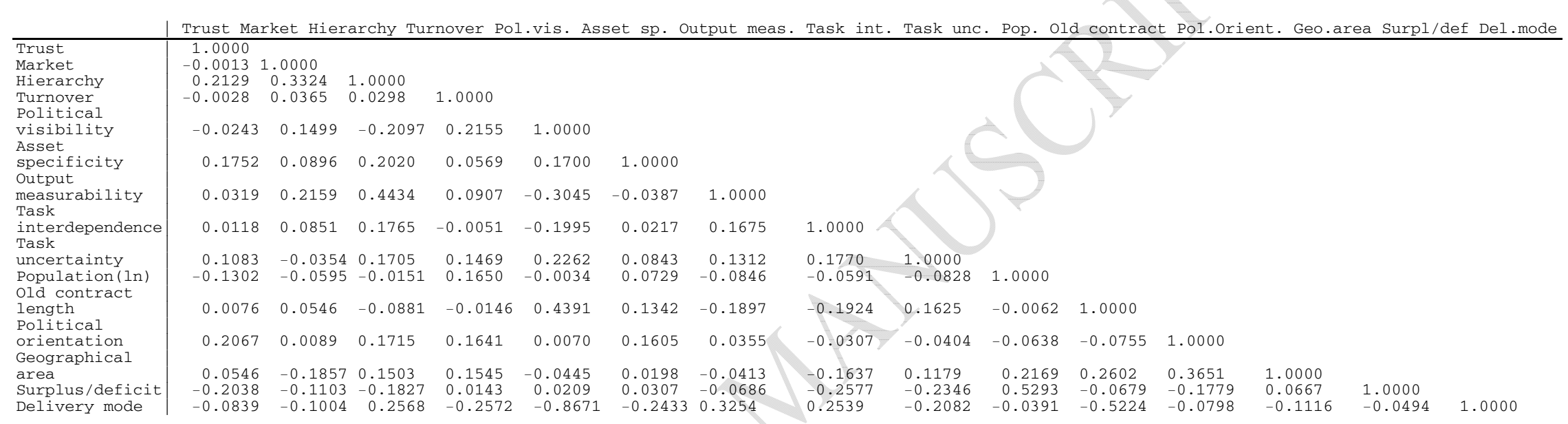

